\title{
PERFORMANCE CRITERIA, TELEMETERED HEART RATE AND ENZYME STUDIES IN OLYMPIC WEIGHT LIFTING
}

\author{
R. GIBBS, F.R.A.C.G.P. \\ 26 Elphinstone Road, Hobart 7000, Tasmania
}

\section{INTRODUCTION}

The sport of Weight Lifting is generally regarded as requiring little else than the possession of great strength, and is not usually differentiated from body-building, in which the sole objective is the attainment of great muscle bulk with maximum definition of muscle segments. Consideration in detail of the specific requirements of competitive weight lifting reveal that the sport is a relatively dynamic one, requiring not only a high degree of strength but also flexibility, speed and specific motor skill.

Though the actual performance in competition is not of itself an aerobic function, the methods used in modern training, when combined in a standard training programme are partly aerobic in nature and could therefore contribute to cardiovascular conditioning. When considering prescription or selection of sport and physical development activities for the young, stress is customarily laid on those activities demonstrably producing cardio-respiratory conditioning, such as rowing, swimming, basketball. (Åstrand and Rodahl 1970, Cooper 1968).

The increasing awareness of the role of endurance exercise in the prevention of coronary disease has underlined this recommendation. In this paper some physiological responses to weight lifting are considered, and also some parameters in weight lifters.

In 1966 Åstrand and Saltin studied maximum oxygen uptake $\left(\mathrm{VO}_{2}\right.$ max) in 120 international athletes and included three weight lifters in their study.

The lifters had an average $\mathrm{VO}_{2} \max$ of $4.5 \mathrm{l} / \mathrm{min}$, between $52-59 \mathrm{ml} / \mathrm{kg} / \mathrm{min}$ : untrained student controls ranged from $38-48 \mathrm{ml} / \mathrm{kg}$. (Av. 3.11).

Members of a weight lifting club, who had trained solely in weight lifting for the past two years were studied. Age ranged from 17-29 years. Parameters considered were Skinfold Measurements, Flexibility, Predicted $\mathrm{VO}_{2}$ max, Watt Performance, Heart Rate Response. Enzyme Studies were also performed.

\section{METHODS AND RESULTS}

\section{Skinfold Measurements:}

Skinfold Measurements would seem to be an indication of total body activity, especially in a sport where there is a specific emphasis upon a high protein, high calorie diet. Using Harpenden calipers, triceps, loin and subscapular measurements were taken, and percentage body fat estimated using the tables of Durnin and Rahaman (1967).

\section{TABLE I}

Percentage Body Fat

$\begin{array}{llcl} & \text { Range } & \text { Mean } & \text { S.D. } \\ \text { Height cms. } & 189-169 & 174.7 & \mp 5.5 \\ \text { Weight Kg } & 106-65 & 84.0 & \mp 12 \\ \text { \% Body Fat } & 17.9-10.5 & 14.02 & \mp 9\end{array}$

Those weight lifters studied were not overfat compared with various norms (Shephard 1972) and compared well with body fat percentages for international rowers (Wright et al., 1976). In this respect, it is worth indicating that the subjects of this study had training work loads of $70-120$ tonnes per week!

\section{Flexibility}

Considerable flexibility training is carried out by weight lifters, great emphasis being placed on the acquisition of flexibility for good performance, and injury prevention.

Spine - hamstring - calf flexibility was measured using a standard "sit and reach" test (Wells and Dillon, 1972) ensuring the knees were kept flat using a knee check strap.

Straight leg hip flexion was measured in the following manner. The subject lies on a flat surface, face up, with one knee held flat, with a strap. The knee joint of the other leg was kept fully extended, by means of an aluminium and 'Velcro' knee splint, employing a mechanism similar to that used on the arm during intravenous therapy. Using a goniometer having a $40 \mathrm{~cm}$ 
diameter protractor, and with 1 metre arms, the measurement taken was the angle between the posterior margin of the external malleolus of the fully raised splinted straight leg with the foot fully plantar flexed, and the body axis, using the tip of the greater trochanter as the apex of the triangle.

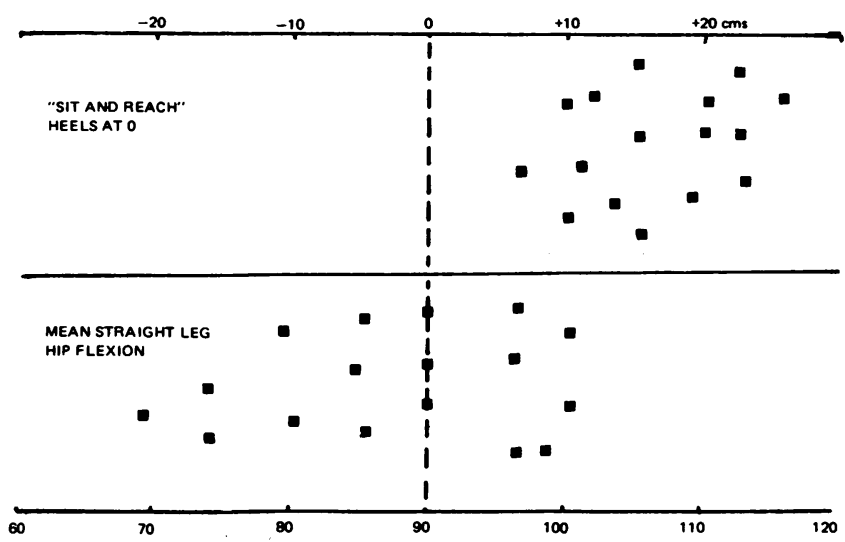

Fig. 1. Flexibility Measurements. "Sit and Reach" Mean straight leg hip flexion. These tests demonstrate a degree of flexibility above the normal, especially in the "sit and reach" test. Comparison was made, with measurements (using the same techniques) on 400 randomly selected Australian males between the ages of 16 and 30 .

\section{Work Tests:}

Using a Repco cycle ergometer with an electronic pre-selector load meter, actuated through a magnetic sensor, and with continuous electro-cardiographic monitoring, a modified work performance test was carried out. Results were corrected to $760 \mathrm{~mm} \mathrm{Hg}$ and $20^{\circ} \mathrm{C}$.
Work load started at approximately 1 watt/kg body weight and was stepped by 50 watts every two minutes.

At a work load of 200 watts the step was held for four minutes to enable maximum oxygen uptake on the basis of heart rate response to submaximal work load to be calculated. Thereafter the work load was stepped by 50 watts every two minutes until exhaustion. This was considered as either inability to maintain rate of work, or the subjects' self-determined inability to continue, in the absence of any third person motivation. From steady state heart rate at known submaximal work load, and known maximum heart rate from work to exhaustion, maximum oxygen uptake was predicted with Åstrand's tables (1970) using the correction for maximum heart rate, (ibid.) not the correction for age. From functions of work load and time worked total performance capacity was integrated in watts for each individual. Five subjects were used for these tests.

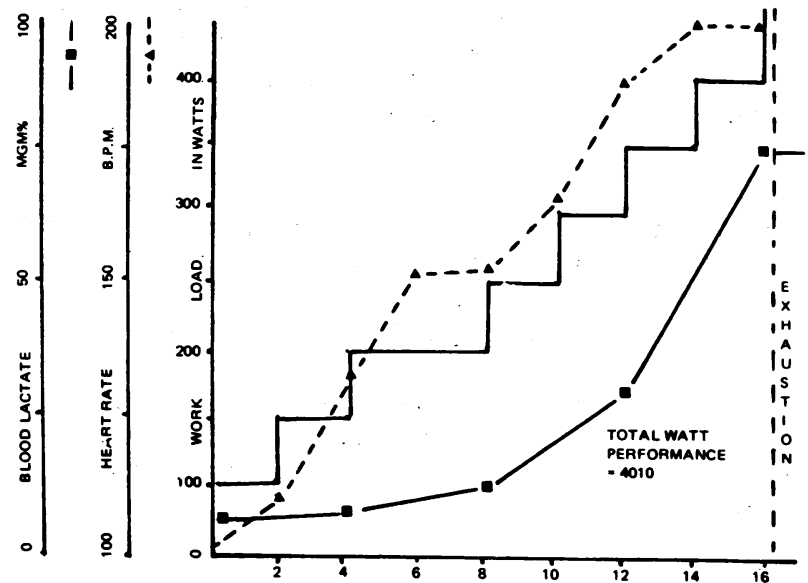

Fig. 2. Model work performance graph

TABLE II

Work Tests

$\begin{array}{llllll}\text { AGE } & \begin{array}{l}\text { WEIGHT } \\ \mathrm{Kg}\end{array} & \begin{array}{l}\mathrm{VO}_{2} \\ \text { I/min } \\ \text { (Predicted) }\end{array} & \begin{array}{l}\mathrm{VO}_{2} \\ \mathbf{m l} / \mathbf{k g} / \mathbf{m i n} \\ \text { (Predicted) }\end{array} & \begin{array}{l}\text { TOTAL WORK } \\ \text { OUTPUT } \\ \text { WATTS }\end{array} & \begin{array}{l}\text { OUTPUT WATTS/Kg } \\ \text { BODY-WT }\end{array} \\ 32 & 80 & 3.48 & 44 & 2050 & \\ 27 & 84 & 3.62 & 44 & 2060 & 25.62 \\ 17 & 74 & 3.6 & 49 & 2000 & 24.5 \\ 23 & 106 & 4.28 & 42 & 2900 & 27.4 \\ 17 & 72 & 3.1 & 44 & 1920 & 26.6\end{array}$

Conclusion:- These tests indicated even grouping of moderate capacity for both aerobic capacity and work performance. 


\section{Heart Rate Response During Competition}

A standard weight lifting programme will last between two and three hours, though only 60-90 seconds may be the total time spent lifting weights in competition. Whilst the lighter or junior lifters are performing, a contestant will spend 10-15 minutes in flexibility and warm-up exercises. Then in an area adjacent to the platform he will parallel the weights lifted in competition with practice lifts of similar weights. He will therefore prepare for up to $\mathbf{9 0}$ minutes before he performs his first or "snatch" lifts in competition. There will be three of these at approximately 5-10 minute intervals. At the conclusion of this section the whole contest is recommenced with light weights, by junior lifters for the second lift the "clean and jerk". The competitor is therefore in some stage of readiness for 2-3 hours with a short rest after the initial maximum effort.

Of particular interest is the area immediately before competition, the time of mental preparation and "mental execution" of the lift preceding the actual physical performance of the lift.

Radio telemetry was carried out on a 17 year old lifter throughout a competition. Heart rate was calculated from an E.C.G. print-out calibrated at $25 \mathrm{~mm} / \mathrm{sec}$ paper speed, by averaging out four consecutive $R$ waves. This was done at minute intervals throughout the competition, with the exception of the time of competition performance, when the recording was continuous and a paper speed of $50 \mathrm{~mm}$ per second was used for greater accuracy.

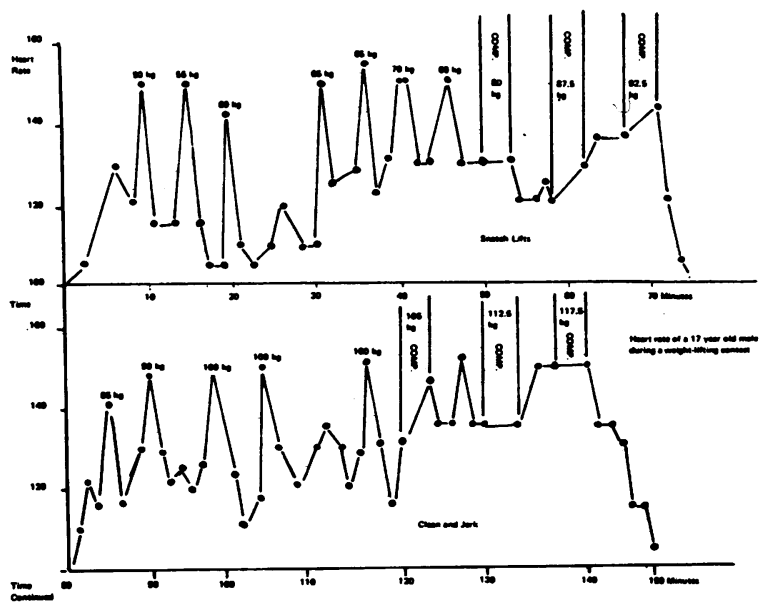

Fig. 3. Overall Activity during a contest

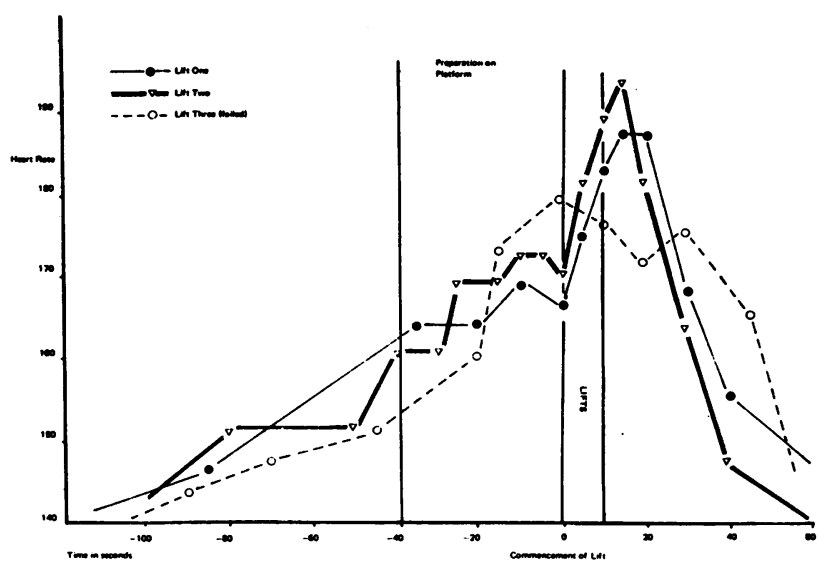

Fig. 4. Heart rate during a "Snatch" Competition Lift

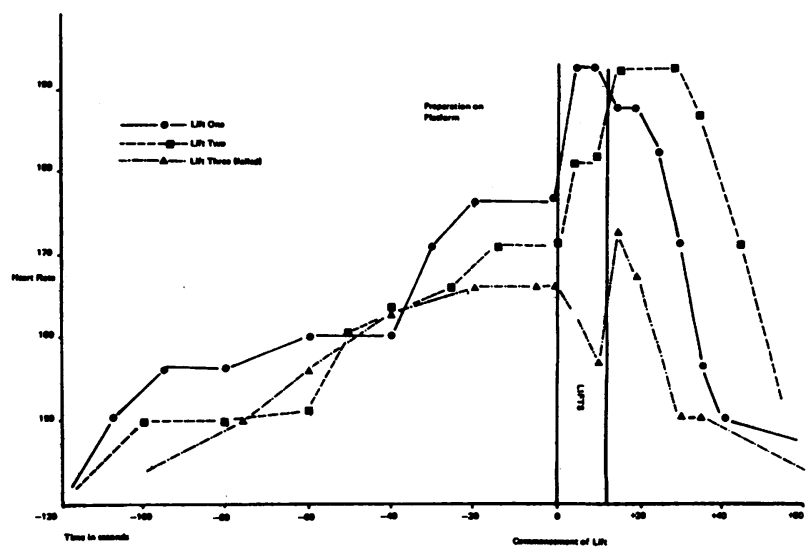

Fig. 5. Heart rate during a "Clean and Jerk" Competition Lift

A heart rate rising to 150 beats per minute during warm-up and lifting indicates moderate aerobic activity though the overall rate of $120 / \mathrm{min}$ is below the level considered necessary for any conditioning effect in a young adult with maximum heart rate of 200-210/minute (Karvonen et al., 1957; Roskamm, 1967).

Examination of the graphs of the heats competition lifts will reveal a sudden rise in heart rate up to 193 $\mathrm{b} / \mathrm{min}$. commencing immediately before lifting and continuing until the lift is complete. This rise is not however sustained if the lifter fails or "bombs out". 
Increased heart rate at this stage can be due to the following possible causes:-

(1) Psychogenic stimulation producing the pressor amines, adrenalin and nor-adrenalin.

(2) Increased intra-thoracic and abdominal pressure associated with inspiration and breath-holding.

(3) Simultaneous contraction of the major muscle groups of the body; legs, trunk and arms, on lifting, giving a sudden increase in muscle vessel resistance.

Though the first reason is attractive as a cause, the sudden fall in heart rate at failure of a lift, noted in both graphs, would appear to be mainly from the decreased peripheral resistance of widespread muscle relaxation, together with decreased central pressure at expiration.

Had the heart rate rise been due in any degree to pressor amines, their effect would cause the raised heart rate to be maintained for longer than was observed.

\section{Other Measurements; Catechol Amines}

Activation or arousal in sport is accompanied by physiological change. In those sports requiring immediate intensity of action, sympathetic nervous system activity is usually high.

As an index of this activity, levels of catechol amines can be estimated.

Resting urinary catechol amine levels were determined on low activity specimens taken from six subjects after 24 hours without exercise and compared with specimens taken half an hour after the completion of competition, the subjects having voided urine before the competitive lifts. The method of estimation used was that of von Euler and Floding (1955).

Levels of catechol amines in urine after weight lifting are observed to be 2-3 times as high as resting levels. These levels are about $75 \%$ of those found in marathon runners (Karki, 1956).

\section{TABLE III} Resting Catechol Amine Levels
After Competition

52

40

67

47

60

50
( $\mu \mathrm{G}$ per Litre \% Competition To Rest

205

206

233

310

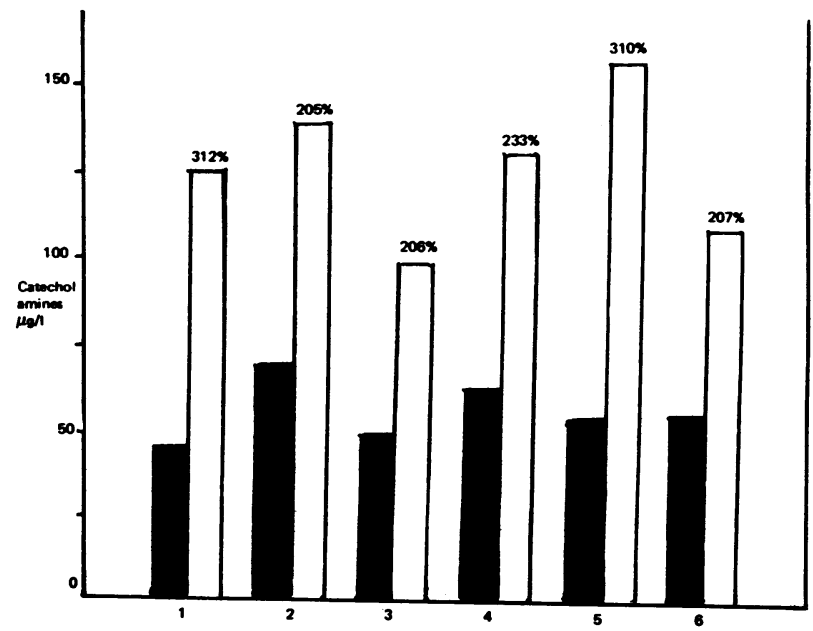

Fig. 6. Catecholamine levels in weightlifters at rest and after competition. \% values are of competition to resting levels.

\section{Enzyme Blood Levels}

It is a well recognised fact that after competition a lifter will be unable to match his competition performance for three or four days. The reasons for this are unknown. Many ideas have been put forward ranging from "release of tension" to muscle oedema or intramuscular haemorrhage.

In organic tissue disturbance, certain enzymes associated with tissue destruction, restitution and repair show raised levels, notably:-

1. Glutamic oxaloacetic transaminase (G.O.T.)

2. Lactic dehydrogenase (L.D.H.)

3. Creatine phosphokinase (C.P.K.)

Of these, creatine phosphokinase is found in increased amounts earliest and most specifically in muscle destruction, e.g. cardiac infarction and muscle wasting diseases (Wells and Dillon, 1972).

C.P.K. levels are raised in exercise, if prolonged (Karki, 1956; Karvonen et al., 1957; Roskamm, 1967). and also if the subjects are untrained (Gibbs, 1976). Levels found in exercise are seen to be in inverse proportion to the degree of aerobic conditioning.

Control valued for L.D.H., G.O.T. and C.P.K. were established and levels were estimated on five subjects from intravenous blood taken thirty minutes after the end of competition. Later tests were desirable but not possible. 
TABLE IV

Enzyme Levels

Before

After

\begin{tabular}{|c|c|c|c|c|c|c|}
\hline $\begin{array}{l}\text { C.P.K. } \\
\text { i.u. }\end{array}$ & $\begin{array}{l}\text { L.D.H. } \\
\text { i.u. }\end{array}$ & $\begin{array}{l}\text { G.O.T. } \\
\text { i.u. }\end{array}$ & $\begin{array}{l}\text { C.P.K. } \\
\text { i.u. }\end{array}$ & $\begin{array}{l}\text { L.D.H. } \\
\text { i.u. }\end{array}$ & $\begin{array}{l}\text { G.O.T. } \\
\text { i.u. }\end{array}$ & $\begin{array}{l}\text { LACTATE } \\
\mathrm{mg} \%\end{array}$ \\
\hline $\begin{array}{l}\text { 1. }-\overline{9} \\
\text { 2. } 139 \\
\text { 3. }- \\
\text { 4. } 161 \\
\text { 5. - }\end{array}$ & $\begin{array}{r}18 \overline{1} \\
11 \overline{4} \\
-\end{array}$ & $\begin{array}{l}\overline{19} \\
\overline{21} \\
-\end{array}$ & $\begin{array}{l}271 \\
379 \\
227 \\
442 \\
340\end{array}$ & $\begin{array}{l}254 \\
227 \\
200 \\
263 \\
196\end{array}$ & $\begin{array}{l}34 \\
39 \\
24 \\
32 \\
46\end{array}$ & $\begin{array}{l}28 \\
35 \\
14 \\
19 \\
17\end{array}$ \\
\hline
\end{tabular}

Normal Values:
C.P.K. 184
i.u.
$\begin{array}{ll}\text { L.D.H. } & 180 \\ \text { i.u. }\end{array}$

$\begin{array}{ll}\text { G.O.T. } & 31 \\ \text { i.u. }\end{array}$

Lactate 12

$\mathrm{mg} \%$

Capillary lactate was estimated from earlobe blood five minutes after competition to measure the degree of anaerobic activity, lest this influence the enzyme studies by acidosis.

Estimations of all enzymes and blood lactate levels were made using the Calbiochem method (1975) on a Union Carbide "Centrificam" centrifugal analyser.

G.O.T. levels were normal throughout. Levels of both L.D.H. and C.P.K. were raised after weight lifting. Both enzymes showed percentage increases comparable to those found after bobsled racing, (Haralambie et al., 1976) an equivalent short high-intensity activity. Acidosis was not high enough to affect the results.

\section{SUMMARY AND DISCUSSION}

Various parameters have been considered in weight lifters. A high degree of strength and of flexibility, but only moderate aerobic capacity and work output is possessed by those studied. Stimulus to cardiovascular conditioning in competition was minimal, except during the competitive lifting.

Catechol amine levels were raised by $200-300 \%$ when compared with resting levels but this is equalled by other sports.
Enzyme studies revealed raised levels of two enzymes - L.D.H. and more significantly C.P.K. Raised C.P.K. levels in exercise are found:-

(a) in untrained people

(b) in prolonged exercise

(c) in very intense short duration exercise.

The rise appears to be in inverse proportion to the aerobic capacity of the subject. Weight lifters have only moderate aerobic capacities. Considering these facts and the high C.P.K. levels found after competition it is reasonable to suggest that considerable tissue anoxia occurs in muscle during weight lifting and this is responsible for the inability of lifters to reproduce their performances on successive days.

Because of the small size of the study and the lack of follow up tests these findings warrant further investigation.

\section{ACKNOWLEDGEMENTS}

I wish to acknowledge the assistance of the staff of the Biochemistry Department, Royal Hobart Hospital in carrying out all the biochemistry. Also to those members of the Tasmanian Weight Lifting Association who took part in the study.

\section{REFERENCES}

Åstrand, P. O. and RodahI, K. 1970, "Health and Fitness" chapter 18 in Textbook of Work Physiology McGraw-Hill, New York.

Ibidem, Prediction of Maximum Oxygen Uptake Appendix A3 p. 618. Ditto, factor for maximum heart rate correction. Appendix A4 p. 620. 
Ibidem, Calculation of Maximum Oxygen Uptake Appendix A6 p. 624.

Åstrand, D. O. and Saltin, B. 1967, Maximum Oxygen Uptake in Athletes - Journ.Applied Physiology, 23, 353-8.

Calbiochem, 1975, Documents nos. L03412 C.P.K., LO3438 - L.D.H., LO31123 G.O.T., LO3063 - Lactate, Calbiochem, La Jolla, California.

Cooper, K. C. 1968, "The Key" chapter 2, in Aerobics, 2nd Edition, Bantam, New York.

Durnin, J. V. G. A. and Rahaman, M. M. 1967, The assessment of the amount of Fat in the human body from measurements of skinfold thicknesses. British Journal of Nutrition, 21 681-689.

Gibbs, R. 1976, to be published, Hobart.

Haralambie, G., Cerny, F. J. and Huber, G. 1976, Serum Enzyme Levels after bobsled racing. Journ.Sports Med.\&Phys. Fitness, 16, 54-56.

Hunter, J. B. and Critz, J. B. 1971, The effects of training on Plasma Enzyme Levels in man. Journ.Appl.Physiol. 36, $214,20-25$.

Karki, N. T. 1956, Urinary Excretion of Adrenalin and Nor-Adrenalin. Acta Physiol.Scand., 39, 74-87.

Karvonen, M. J., Kentala, E. and Mustala, O. 1957, The effects of Training on Heart Rate. Am.Med.Exp.Fenn., 35, 307-11.

Magazanik, A., Shapiro, Y., Meytes, S. and Meytes, I. Enzymes levels and Water Balance, during a Marathon Race. Journ.Appl.Physiol., 36, $214-7$.

Nowacki, P. E., Kustner, W. and Haag, H. 1975, The influence of Exhaustive Efforts at High Altitude $(2040 \mathrm{~m})$ or Serum Enzymes in well trained Athletes. 1:8 in "Metabolic adaptation to prolonged.Physical Exercise" Edited Howald, H. and Poortmans, J. R. Birkhauser Verlag Basel.

Roskamm, H. 1967, Optimum Patterns of Exercise for healthy adults. Journ. Can.Med.Assn., 22, 897-901.

Shephard, R. J. 1972, Alive Man! The Physiology of Physical Activity. Chas. C. Thomas, Springfield.

Vincent, W. R. and Rapaport, E. 1965, Am.Journ.Cardiology, 15, 17-26.

von Euler, U. S. and Floding, I. 1955, Acta Physiol.Scand., 33, Suppl. 118, 57.

Wells, K. F. and Dillon, E. K. 1972, Sit and Reach, a test of Back and Leg Flexibility. Res. Quart. 23, $115-118$.

Wright, G. R., Bompa, T. and Shephard, R. J. 1976, Physiological evaluation of Winter training programmes for Oarsmen. Journ.Sports Med.and Phys. Fitness, 16 22-36. 